\title{
ECONOMETRIC Modeling OF ChINA
}




\section{ECONOMETRICS IN THE INFORMATION AGE:}

\section{THEORY AND PRACTICE OF MEASUREMENT}

Series Editors: Lawrence R Klein (Univ. of Pennsylvania)

Kanta Marwah (Carleton Univ.)

Published

Vol. 1 Selected Papers of Lawrence R Klein: Theoretical Reflections and Econometric Applications edited by Kanta Marwah

Forthcoming

Vol. 2 The Chinese Economy in the Twenty-First Century

- An Econometric Approach

Lawrence J Lau 
Econometrics in the Information Age: Theory and Practice of Measurement - Vol. 3

Series Editors: Lawrence Klein \& Kanta Marwah

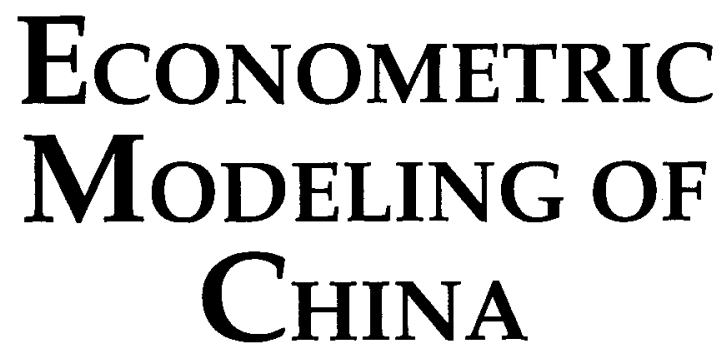

Editors

Lawrence R. Klein

University of Pennsy/vania, USA

Shinichi Ichimura

ICSEAD, Japan 


\section{Published by}

World Scientific Publishing Co. Pte. Ltd.

P O Box 128, Farrer Road, Singapore 912805

USA office: Suite 1B, 1060 Main Street, River Edge, NJ 07661

UK office: 57 Shelton Street, Covent Garden, London WC2H $9 \mathrm{HE}$

\section{British Library Cataloguing-in-Publication Data}

A catalogue record for this book is available from the British Library.

\section{ECONOMETRIC MODELING OF CHINA}

Copyright $\odot 2000$ by World Scientific Publishing Co. Pte. Ltd.

All rights reserved. This book, or parts thereof, may not be reproduced in any form or by any means, electronic or mechanical, including photocopying, recording or any information storage and retrieval system now known or to be invented, without written permission from the Publisher.

For photocopying of material in this volume, please pay a copying fee through the Copyright Clearance Center, Inc., 222 Rosewood Drive, Danvers, MA 01923, USA. In this case permission to photocopy is not required from the publisher.

ISBN $981-02-4383-9$ 


\section{To Sonia and Yukiko}


This page is intentionally left blank 


\section{Foreword}

These are the up-to-date fruits of our efforts in econometric modeling of China at the International Center for the Study of East Asian Development, Kitakyushu, Japan. ICSEAD was established as a joint undertaking with the University of Pennsylvania in 1989, and ever since its inception, it has followed the suggestion of Professor Lawrence R. Klein to maintain econometric models and their data banks of East Asian economies. It has held the work-shops for this purpose and published a number of proceedings. Moreover, on the basis of our own econometric models we have made the predictions of the East Asian Economies available in our quarterly journals every year.

In particular, we have emphasized the quantitative studies of the Chinese economy among others. Inviting a number of economists from China, we have been working with them on the econometric models of China. We will continue to do so in the future. This book tries to make available all the econometric models of China presented at our workshop held at ICSEAD in 1998, together with the statistical data used for their model building. The editors asked all the authors not only to revise their original papers considering the comments given at the workshop but also to provide the reader with almost all the basic statistical data that they used to estimate their own models. We believe that the most important and difficult part of econometric work on the Chinese economy is indeed the preparation of reliable statistical data. The reader will have the benefit of learning about reliable data and their sources.

The benefit of this statistical information can hardly be over-emphasized, not only for the studies of Chinese economy but more generally for the advancement of econometric work. The progress of empirical work in econometrics will be improved substantially if the data used in the estimation and tests of the models are offered at the same time. As theoretical physics and experimental physics naturally develop side by side, so econometrics should develop in theory and its empirical applications side by side. But unlike physics, the empirical work in econometrics requires enormous efforts in searching for and compiling the statistical data needed for model building. For this reason we believe that despite the difficulties we must try to make the data 
as well as the models available to the reader. Only then can the re-examination and testing of published econometric works be meaningful and easily used by other econometricians. The benefit will be for both initial research workers and their followers. The cumulative process of empirical research will be much faster and productive, so that further improvement in applied econometrics may be expected. This is particularly important for econometric work on the Chinese economy, where statistical data are still unsatisfactory and require careful treatment.

Almost half a century has passed since I first met Sonia and Lawrence R. Klein in Ann Arbor in 1953. Moreover, our family association has lasted more than forty years. We have learned a great deal from the association with their family. This may not be too common nowadays. As a token of our many years of friendship and professional and family association, we would like to dedicate this joint effort to our two wives whose dedication made it possible to produce this unique volume at this time.

March 3, 2000

Shinichi Ichimura 


\section{CONTENTS}

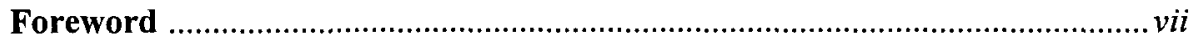

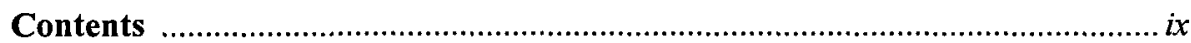

List of Tables and Figures ..........................................................................

Introduction to: Econometric Modeling of China ................................................ 1

Chapter 1 A Model Study of Balance of Payments and

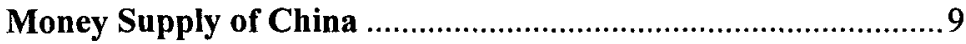

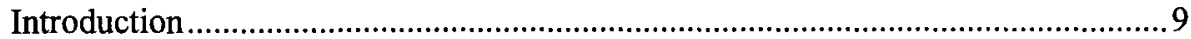

1. Characteristics of the Chinese Balance of Payments......................................... 12

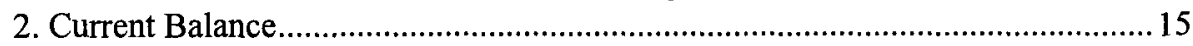

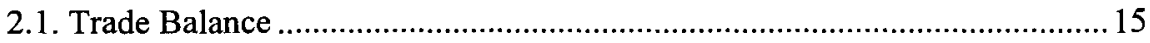

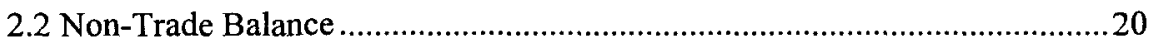

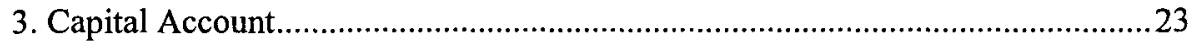

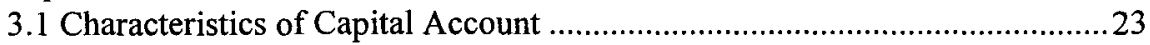

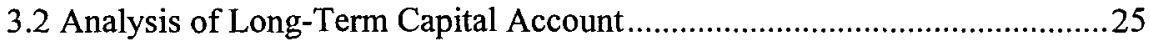

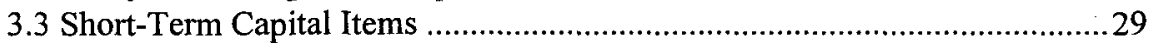

4. Balance of Payments and Money Supply .......................................................... 31

4.1 Balance of Payments and Foreign Exchange Reserves....................................31

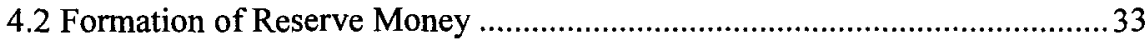

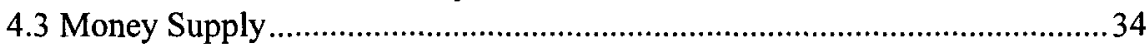

4.4 Influence of Monetary Supply on the Economy ……...................................37

4.5 Relationship between Money Supply $\mathrm{M}_{1}$ and Nominal GDP ......................38

4.6 Relationship between Money Supply and Price Level..................................39

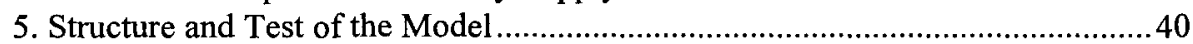

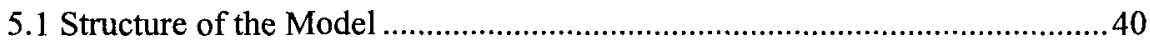

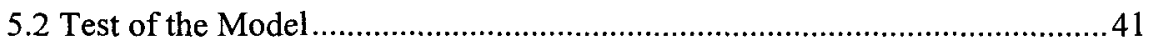

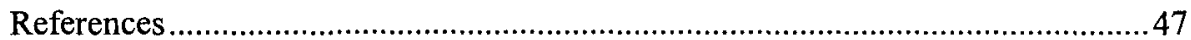

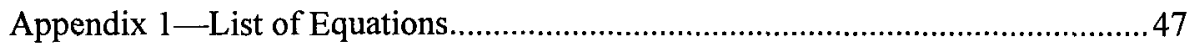

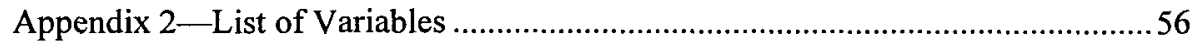

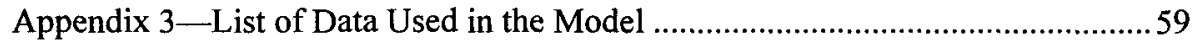

Chapter 2 ICSEAD'S Econometric Model of the Chinese Economy.........67

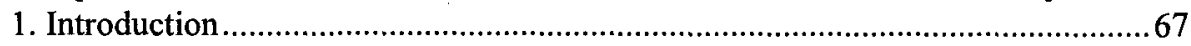

2. Econometric Models of the Chinese Economy: Brief Historic Review ..............68

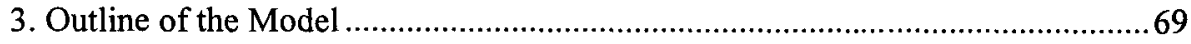

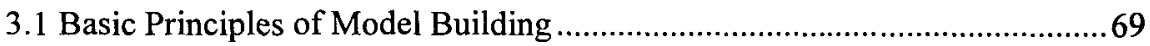

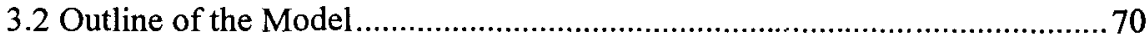

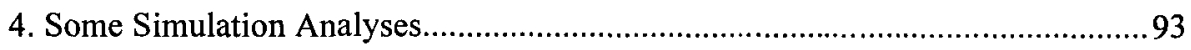




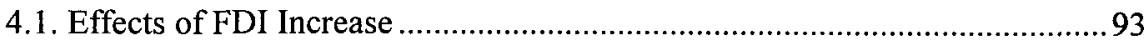

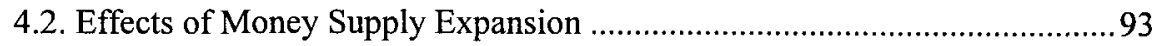

4.3. Effects of Increase in Government Consumption ......................................94

4.4. Effects of Increase in Public Investment...................................................94

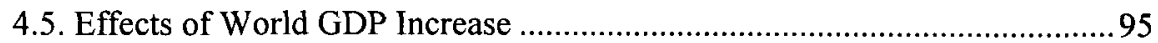

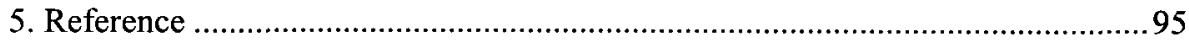

Appendix A — China Macro Econometric Model 1997 Version Equation List........96

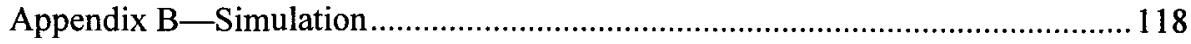

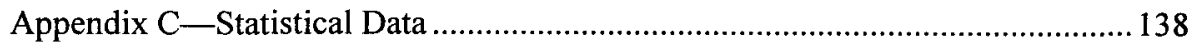

Chapter 3 Outline of the PAIR China-Hong Kong Link Model .............151

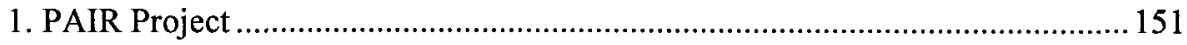

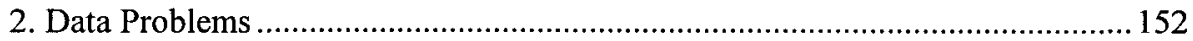

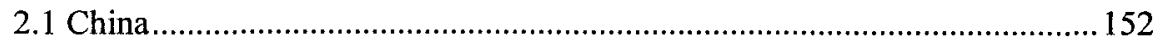

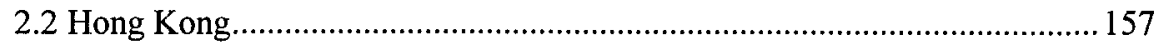

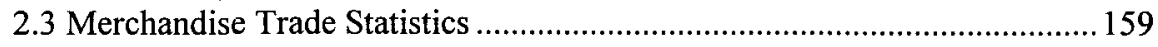

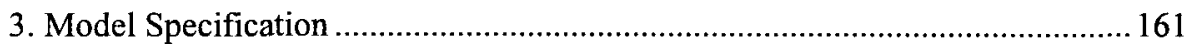

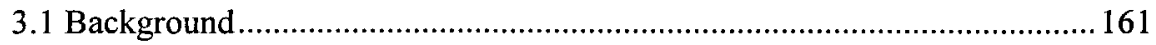

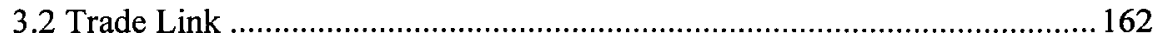

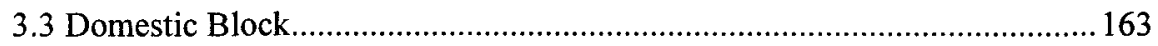

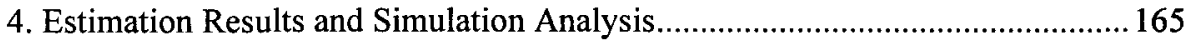

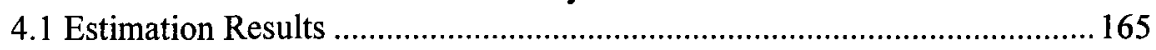

4.2 Simulation Analyses of Exchange Rate Policy ….................................... 166

Appendix 1. Estimation Results of RRXM ................................................... 171

Appendix 2. Structure of Trade Block in PCHLM...........................................172

Appendix 3. Price Determination Structure of China Block ...............................173

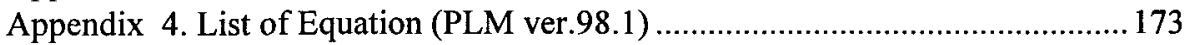

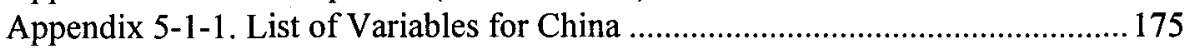

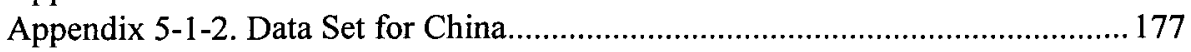

Appendix 5-2-1. List of Variable for Hong Kong ............................................... 179

Appendix 5-2-2. Data Set for Hong Kong .........................................................181

Appendix 6. Estimation Results of Equations................................................. 185

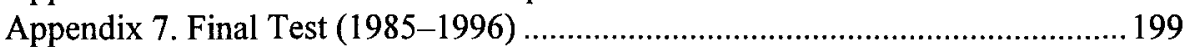

Chapter 4 China's Econometric Model for Project PAIR .....................201

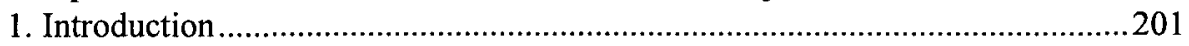

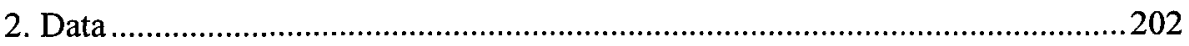

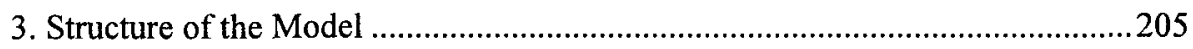

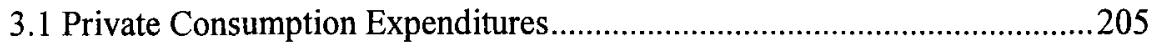

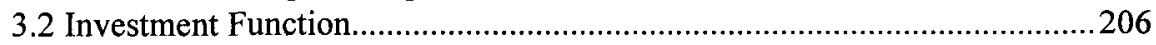

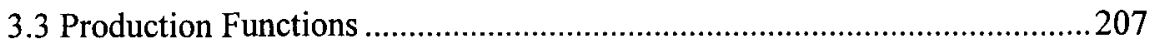




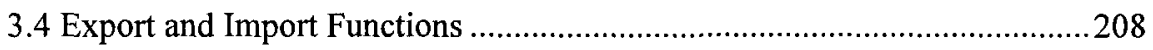

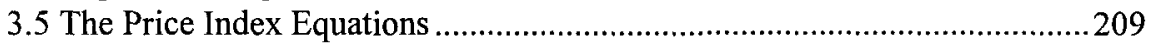

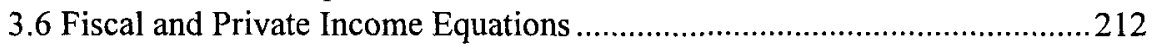

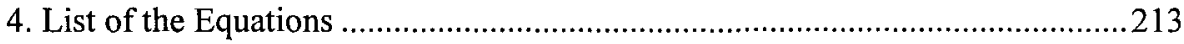

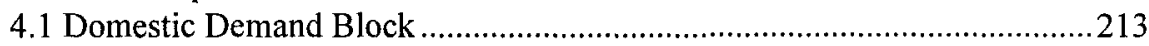

4.2 Production and Gross Domestic Product Block........................................214

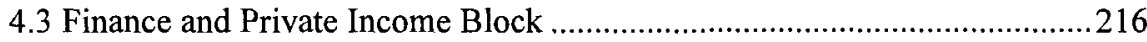

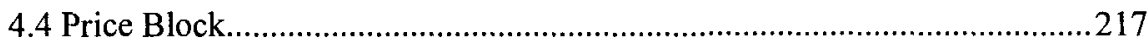

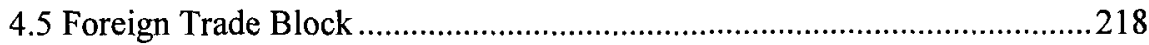

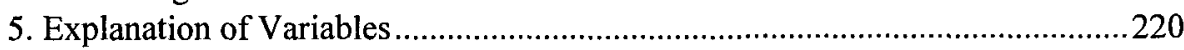

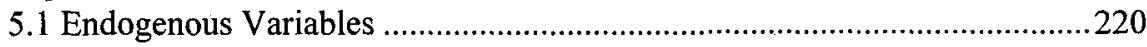

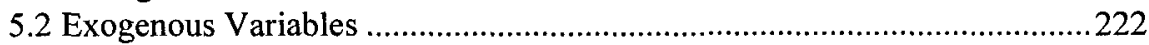

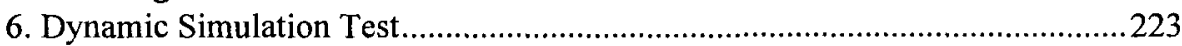

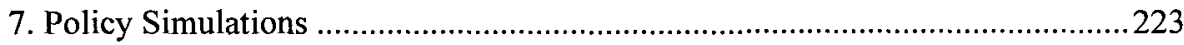

7.1 Impacts of an Increase of 10\% in Nominal Public Consumption. ..............223

7.2 Impacts of a 10\% Increase in Fixed Investment Loans...............................224

7.3 Impacts of an Increase of $10 \%$ in Tax Revenues on Agriculture,

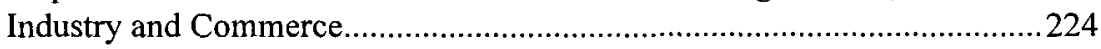

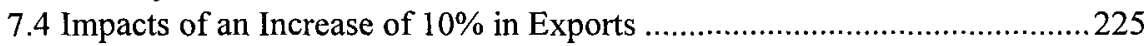

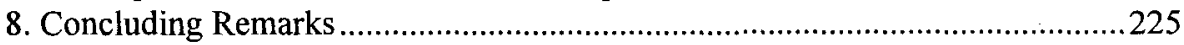

APPENDIX: China's Economic Model for Project LINK....................................239

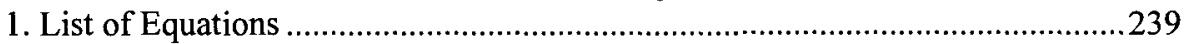

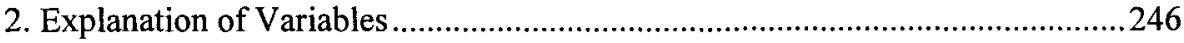

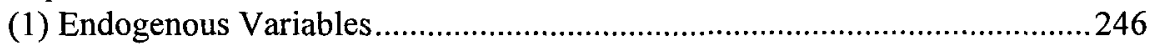

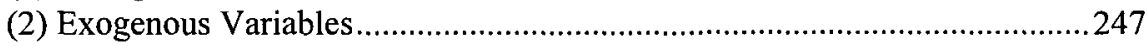

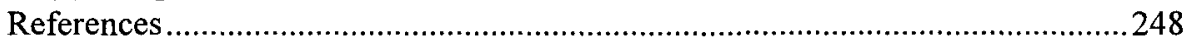

Chapter 5 A Computable General Equilibrium Model for

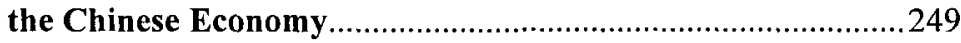

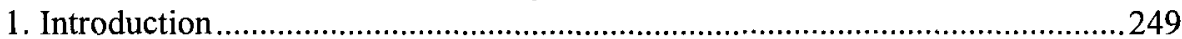

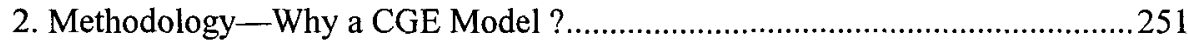

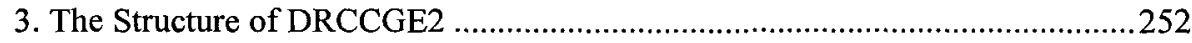

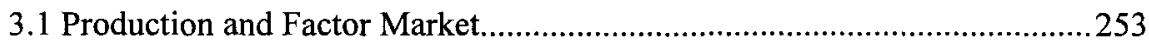

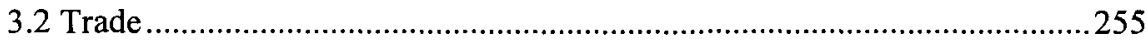

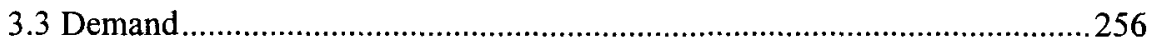

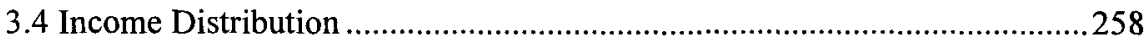

3.5 Government and the Extra-Budget Public Sector ....................................259

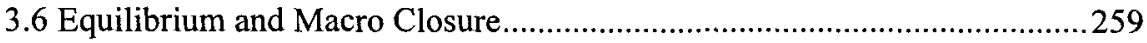

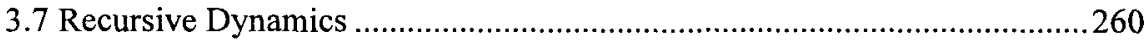

4. Model Calibration and the Benchmark Equilibrium Data Set.........................261

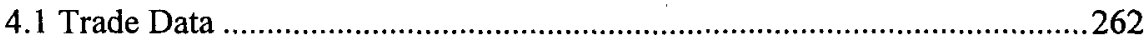




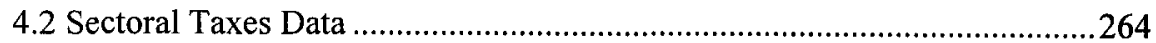

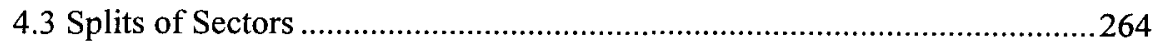

4.4 Estimating the Input-Output Matrix of Production for Processing Exports

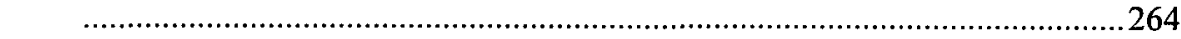

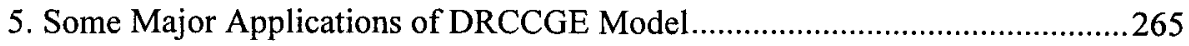

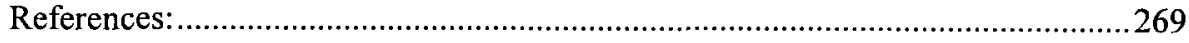

Appendix A-Sector Classification in DRCCGE2 and Their SSB-IO Sector

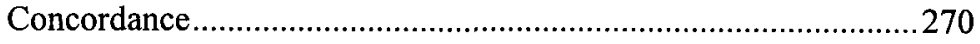

Appendix B-Algebraic Specification of CGE Model for China ........................2273

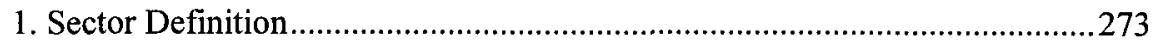

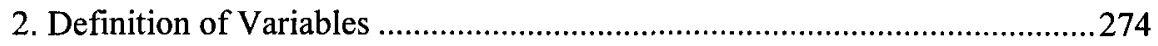

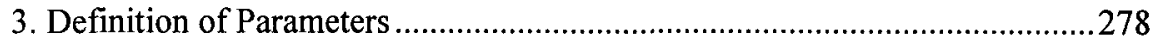

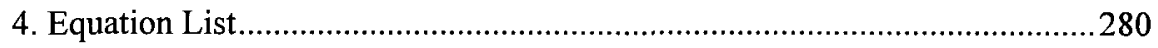

Chapter 6 Natural Decomposition of Total Factor Productivity

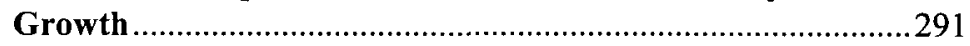

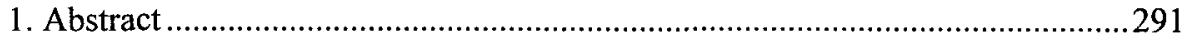

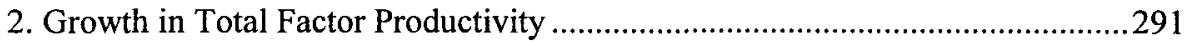

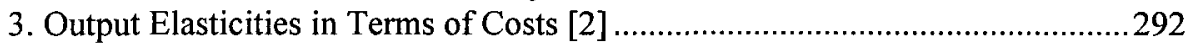

4. Decomposition of Total Factor Productivity Growth.......................................294

5. Decomposition of Product Output Growth .......................................................296

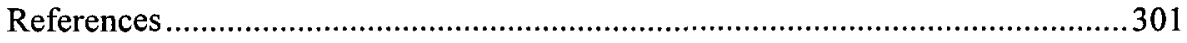

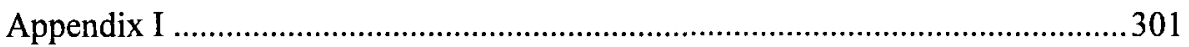

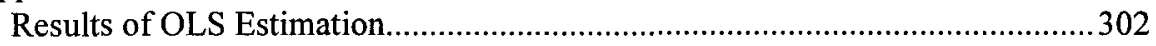

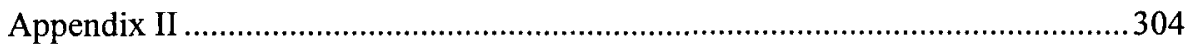

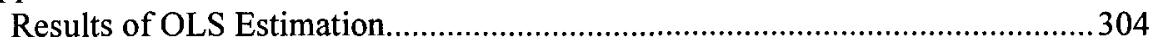

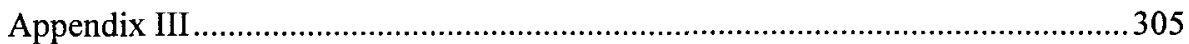

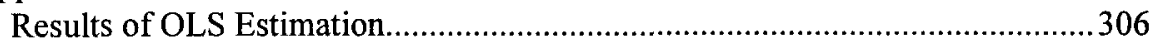

Chapter 7 China's Macro Econometric Annual Model ............................307

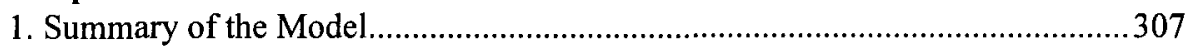

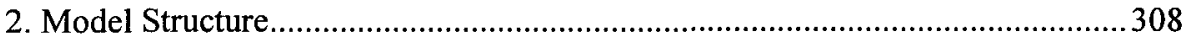

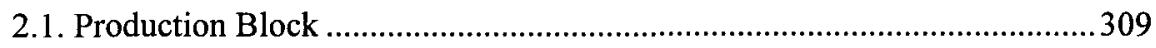

2.2. Population and Labor Force Block …...................................................... 310

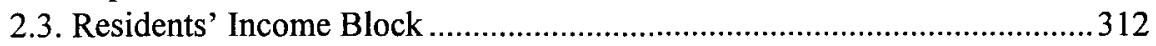

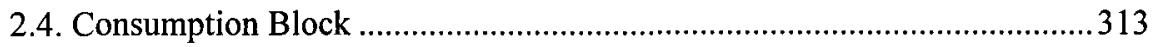

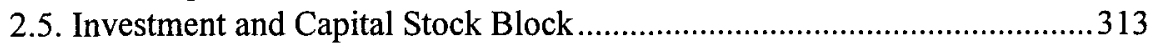

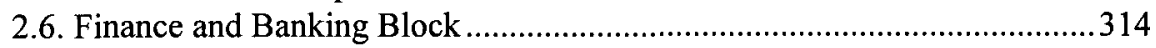

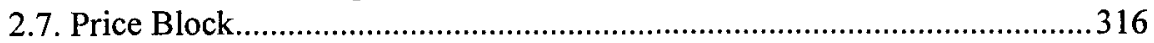

2.8. Foreign Capital and Foreign Trade Block.............................................317

3. Model Application and Problems................................................................... 318 
Chapter 8 A Retrospective View of the Asian Financial Crisis: Special Reference to Exchange Rate Policy .............................321

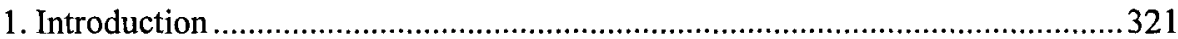

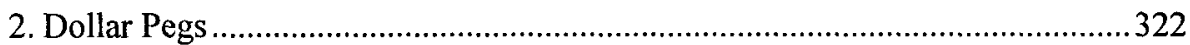

3. How Large is the Effect of Exchange Rate Policy? .........................................326

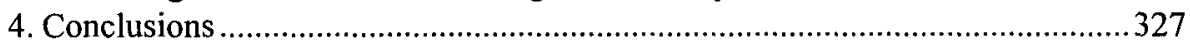

Appendix A: Estimated Equations and the Coefficients ....................................328

Appendix B: Summary of Simulation Results .................................................339

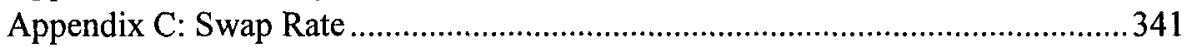

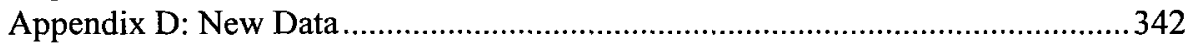

Chapter 9 Output and Price Determination in Chinese

Macroeconometric Models ........................................................363

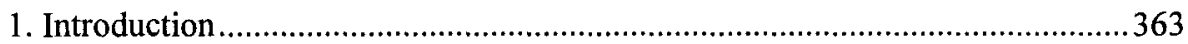

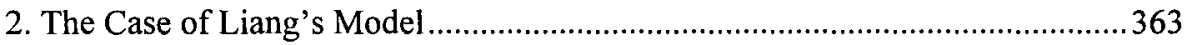

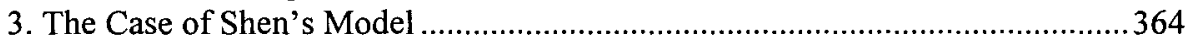

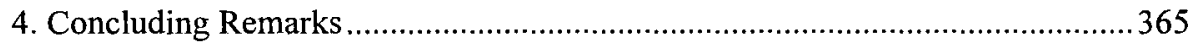

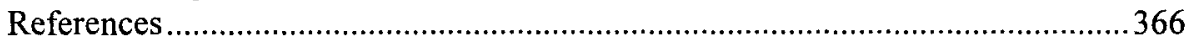

\section{Chapter 10 A Note on the Statistical Data of China: Population}

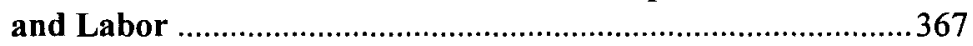

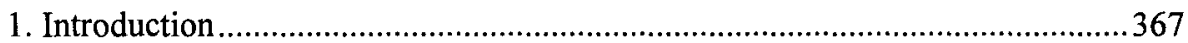

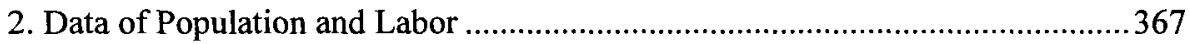

3. Economically Active Population and Employed Persons ................................368

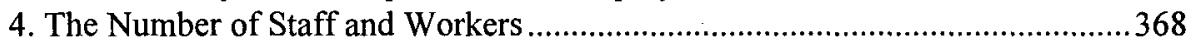

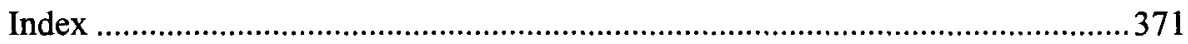




\section{LIST of TABLES and FIGURES}

Chapter 1 A Model Study of Balance of Payments and Money Supply of China

Table 1-1 Chinese Balance of Payments (1982-1996) .......................................13

Table 2-1 Structural Changes of the Imports and Exports of China.......................16

Table 2-2 Influential Factors of Different Categories of Exports.........................18

Table 2-3 Influential Factors of Different Categories of Imports..........................19

Table 2-4 Contribution of Foreign-Funded Enterprises to Total Exports ............. 19

Table 2-5 Non-Trade Balance and Its Components .........................................21

Table 3-1 Structure of Utilization of Foreign Capital ........................................24

Table 3-2 Balances of Types of Long-Term Capital .........................................26

Table 3-3 The Flow of Short-Term Capital and Its Structure ...............................30

Table 4-1 China's Reserves and Its Components .................................................32

Table 4-2 Balance Sheet of Monetary Authorities (End of 1996) .......................33

Table 4-3 Main Asset Items of Monetary Authorities And Reserve Money ..........34

Table 4-4 Balance Sheet of Deposit Money Banks (1996-End).......................... 35

Table 4-5 $\quad M_{2}$, Reserve Money $M B$ And Monetary Multiplier $m \ldots \ldots \ldots \ldots \ldots \ldots \ldots \ldots . . . . . . . . . .36$

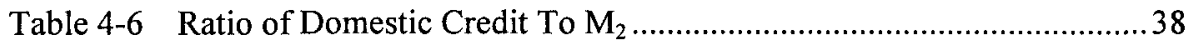

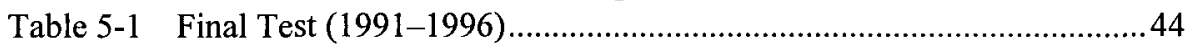

Figure 5-1 Flow Chart of The Model ............................................................... 41

Figure 5-2 Final Test of The Model For Some Variables.....................................43

\section{Chapter 2 ICSEAD'S Econometric Model of the Chinese Economy}

Table 1 Estimation Results of the Production Function.....................................75

Table 2 Gross Domestic Product and Expenditure .......................................... 76

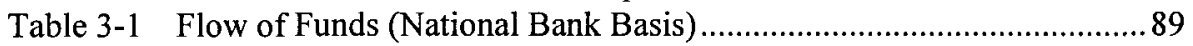

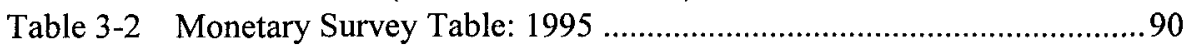

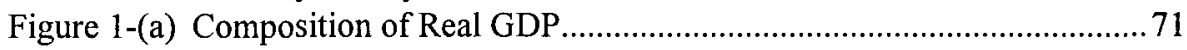

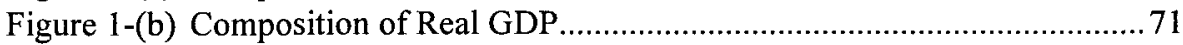

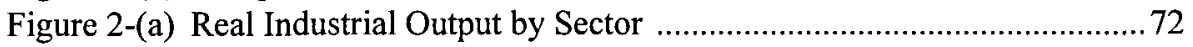

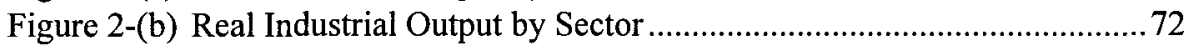

Figure 3 Growth of Output, Employment and FDI in Non State-Owned

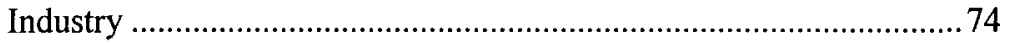

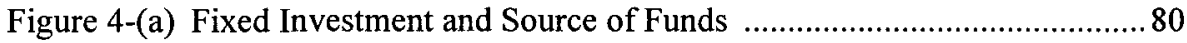

Figure 4-(b) Composition of Source of Funds for Fixed Investment .....................8 80

Figure 5 Income Difference and Urban Population Ratio ............................. 84

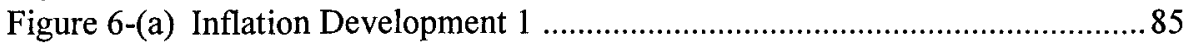

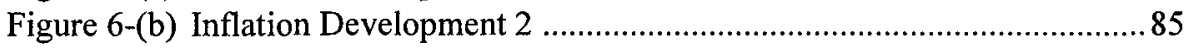

Figure 6-(c) Factor Decomposition of Retail Price Inflation................................. 86

Figure $7 \quad$ Growth of Total Loan and Bank Credits ....................................... 91 


\section{Chapter 3 Outline of the PAIR China-Hong Kong Link Model}

Table 1 Estimates of Export/Import Deflators ...........................................155

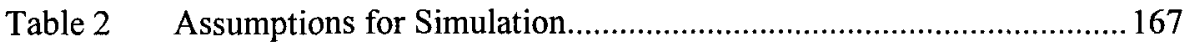

Table 3 Summary of Simulation Results.....................................................167

Table 4 Impacts on Merchandise Trade(US Dollar Term: 1990 Prices) .......... 168

Table 5 Impacts on Trade Prices(Local Currency Term) ............................... 168

Table 6 Impacts on Trade Prices(US Dollar Term) .........................................169

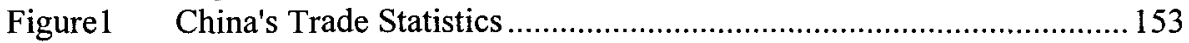

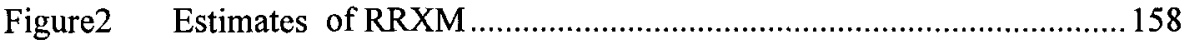

Figure3 Trade between China and Hong Kong ...............................................159

Figure4-1 Share of Main Destination in China's Export...................................160

Figure4-2 Share of Main Origin in China's Imports ......................................... 161

Chapter 4 China's Econometric Model for Project PAIR

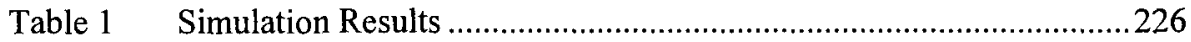

Table 2 Impacts of $10 \%$ Increase in Public Consumption on Major Endogenous Variables.....................................................227

Table 3 Impacts of 10\% Increase in Fixed Investment Loan on

Major Endogenous Variables.

Table 4 Impacts of a Sustained Increase of $10 \%$ in Tax Revenues on Agriculture, Industry and Commerce over The Period 1987-1992 on Major Endogenous Variables.

Table 5 Impacts of 10\% Increase in Exports of Goods and Services on Endogenous Variables.

\section{Chapter 5 A Computable General Equilibrium Model for the Chinese} Economy

Table 1 Standard Accounting Matrix and Related

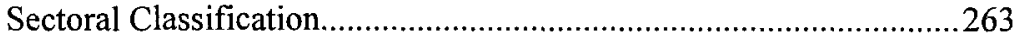

Table 2 Some Major Applications of DRCCGE ...........................................265

Table 3 A Marco SAM Chinese Economy, 1995 (100Mn Yuan) ...................266

Figure 1. Structure of Production ..................................................................2. 254

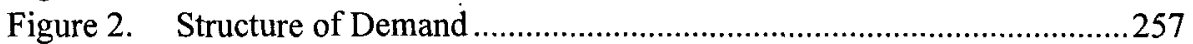

Chapter 6 Natural Decomposition of Total Factor Productivity Growth

Table 1 Comparison of China's and the US Economies.

\section{Chapter 7 China's Macroeconometric Annual Model}

Table 1 Total Population and Forecast (Mid-year).

Figure 1 Diagram of China's Macro Econometric Annual Model 
Chapter 8 Estimation of Effects of Exchange Rate Policies: China and Other East Asian Economies

Table 1 Current Account of East Asian Economies 323

Table 2 Long Run Elasticity of Relative Prices and Real Income 339

Table 3 Long Run Elasticity of Relative Prices and Real Income 340

Table 4 Summary of Simulation Results

Chapter 9 Output and Price Determination in Chinese Macroeconometric Models

Figure 1: Price Determination in Liang Model 364

Figure 2: Price Determination in Shen Model 